\title{
PERFORMANCE MEASUREMENT IN IRISH NONPROFIT ORGANISATIONS - AN EMPIRICAL STUDY ON THE STATE OF PLAY
}

\author{
Francis McGeough \\ Institute of Technology Blanchardstown
}

\begin{abstract}
Tonprofit organisations (NPOs) depend on trust and the appearance of com1 petency to maintain legitimacy in the eyes of the general public upon whom they depend for funding. In the absence of an all-embracing figure such as profit, NPOs can use the provision of performance information to demonstrate their competency. Using a performance framework, this research analyses the quantity and variety of performance information provided by 50 of the largest NPOs in Ireland. It is found that there is much room for improvement as most NPOs are providing very limited performance information.
\end{abstract}

\section{INTRODUCTION}

Nonprofit organisations (NPOs) play an increasingly important role in the delivery of services in many countries. They rely on their reputation in order to maintain their funding from government sources and from the general public. However, in recent times, the NPO sectors in the UK and Ireland have been beset by scandals arising from concerns about their approach to fundraising, salary levels, and how much of the money raised is spent on the beneficiaries whom the NPO serves. In the specific case of Ireland, the reputations of a number of prominent NPOs in Ireland were badly damaged by the publicity arising from high pay levels, inappropriate expenditure and the use of NPO funds to pay for pension top-ups. These scandals have focused attention on the NPO sector in Ireland and questions have been raised about the role and purpose of many NPOs and whether there is too much duplication. The crucial question being asked is whether the sector is delivering value for 
money. For example, there are over 4,700 registered NPOs listed on the Charities Regulatory Authority's (CRA) website. In addition, there are over one hundred registered NPOs dealing with cancer. These figures should be examined in the light of Ireland's population which is around 4.6 million.

The establishment of the CRA has focused attention on the role and performance of NPOs in Ireland. The CRA's role is to increase public trust in the management of NPOs, increase accountability and ensure the effective use of assets (Charities Regulatory Authority, 2014). Therefore, the focus of this article is to examine how NPOs can report their achievements and to what extent that they are doing so. It can be argued that the provision of performance information may help to allay concerns about their efficiency and effectiveness.

As a result of the increased role of NPOs in the delivery of public services, there is a demand for increased scrutiny of these organisations and the results that they are achieving (Connolly and Dhanani, 2009). In addition, NPOs depend on public trust in order to survive, which may be gained or maintained through the provision of information on good performance. It is suggested that a 'trustworthy charity is one that meets the expectations of the public' (Yang et al., 2014, p. 791). However, this can be a two-edged sword because if the information shows the NPO in a poor light, there may be repercussions for the organisation (Dhanani and Connolly, 2012). Nonetheless, the provision of performance information can help to maintain or improve the legitimacy of the NPOs in the eyes of the general public.

It is argued that given their valued status in society due to their good deeds, they are particularly susceptible to public disillusionment when things go wrong (Gibelman and Gelman, 2004). This point is further emphasised when Jeavons (1994) when he suggests that the public expect to be let down by private companies but that when it comes to NPOs, they have a higher set of standards. Therefore, NPOs must ensure that they maintain their reputation and legitimacy in the eyes of the general public.

There has been limited research on performance reporting by NPOs in Ireland. A previous study (Connolly and Hyndman, 2004) found that Irish NPOs published substantially less performance information than NPOs in UK. This study suggested that this was due to the weaker legislative and regulatory environment a lack of focus on control and monitoring, and limited investigation by researchers. However, changes are happening - the Charities Act, 2009 sets out a legislative framework for managing NPOs and the establishment of the CRA in 2014 likely leads to tighter regulation of the sector. In addition, legitimacy theory suggests that NPOs can continue to exist only if they are seen as legitimate and legitimacy is based on trust and the maintenance of a 'social contract'. In other words, the NPO values must be in accord with those of wider society (Lindblom, 1994; Mathews, 1993; Shocker and Sethi, 1973). The scandals mentioned above have increased focus on the sector.

The purpose of this paper is to build on the earlier work by Connolly and Hyndman (2004) by identifying the quantity and variety of performance indicators published by a sample of large Irish NPOs, and this will be examined through the lens of legitimacy theory. This paper contributes to the literature in two ways. Firstly, using legitimacy theory to contextualize NPO performance, it develops a framework for the reporting of performance through public disclosures. Secondly, 
employing this framework, it assesses the quantity and variety of performance information provided by 50 of the larger NPOs in Ireland.

The format of the paper is as follows: the next section examines legitimacy theory as the theoretical framework for the subsequent empirical work, the difficulties involved in the measurement of performance in NPOs and the key elements of a performance management system for NPOs. Following that the methodology used in the study and the research findings are outlined. The final section outlines the conclusions and areas for further research.

\section{THEORETICAL FRAMEWORK - LEGITIMACY THEORY}

As outlined above, trust is a critical element for NPOs, and legitimacy theory places great emphasis on the need to maintain and develop trust. Legitimacy theory has been widely used as a framework for analysing company disclosures related to corporate social responsibility (Campbell et al., 2006; Deegan, 2002; Tilling and Tilt, 2010) and largely centres on the idea that organisations can gain acceptance by meeting society's expectations (Samkin and Schneider, 2010). However, it has not been widely used by scholars in relation to NPOs but it is suggested that legitimacy theory is well suited to NPOs because of the '...focus on strategies organizations employ, above and beyond legal requirements, to negotiate the demands of various stakeholders with different levels of authority in a complex environment' (Tremblay-Boire and Prakesh, 2015, p. 696).

Legitimacy theory suggests that organisations can only continue to exist if they are considered legitimate (Deegan, 2002). It is argued that an organisation is legitimate if its values are in line with society's values. However, if there are different sets of values, then the organisation may lose its legitimacy (Lindblom, 1994). Legitimacy has been defined in the following terms: 'Legitimacy is a generalized perception or assumption that the actions of an entity are desirable, proper, or appropriate with some socially constructed system of norms, values, beliefs and definition' (Suchman, 1995, p. 574). It has been closely linked to the idea of a social contract which suggests that organisational survival is threatened if this contract is breached (Mathews, 1993; Kent and Zunker, 2013). A social contract whether expressed or implied can be defined in terms of the delivery of socially desirable ends or the distribution of benefits to different groups (Shocker and Sethi, 1973). Furthermore, Shocker and Sethi argue that NPOs must constantly meet the twin tests of legitimacy and relevance by showing that society requires its services and that the groups benefiting from its existence have the society's approval.

Trust and public confidence are critical elements for NPOs, and these must be maintained in order for the organisation to remain legitimate and survive long-term (Connolly et al., 2013; Mueller et al., 2005; Taylor and Taylor, 2014). Therefore, legitimacy can be seen as a resource that establishes the NPO's credibility and therefore gives continued access to resources (Luke et al., 2013). Furthermore, it is argued that trust requires the organisation to show that it is well managed and make a positive difference to the cause that they are working on (Taylor and Taylor, 2014; Sargeant et al., 2006). This suggests that NPOs need to be able to show how the money was being 
spent; for example, how much of the NPO's funds were being spent on the client as opposed to administration, and what impact was the NPO having on the beneficiaries of its programmes. This requires the NPOs to measure the outcomes and performance, and communicate achievements to their stakeholders in order to maintain their legitimacy (Moxham, 2014). The performance framework outlined below is a basis for NPOs to report on their achievements to their stakeholders.

Thus, public disclosure of performance information can help in developing trust and legitimacy (Deegan, 2002; Yang et al., 2014). Taylor and Taylor (2014) agree with this when they argue that donors depend on trust and trust relies on the perception of performance. Therefore, donors are likely to demand more performance information as evidence that their donations are being spent efficiently and effectively. LeRoux and Wright (2010, p. 584) argue that performance information can convey their achievements to their stakeholders and they outline their views as follows: '...nonprofits can use performance measurements not only to report achievements but also to ensure their survival and success within the sector. Performance measurement can help nonprofits to better manage their programs, services and resources, in their marketing efforts; in strengthening their relationship with stakeholders; and in conveying their record of performance to current and prospective clients, donors, volunteers and board members.' This suggests that performance information that shows the NPO in a good light will help the organisation to maintain the public's trust and be seen as legitimate. However, this could be a 'double-edged sword' because if some of the information being put into the public arena is negative, this could have a serious impact on the NPO. This is particularly the case when media reporting tends to be negative because it is argued that the media ignores success or balances accounts in favour of an increased focus on the negative (Flinders, 2011).

Trembay-Boire and Prakesh (2015) argue that trust is a crucial issue for NPOs for two reasons. Firstly, to protect the organisation's ability to raise funds when scandals hit other NPOs. Suchman (1995, p. 579) also agrees that a legitimate organisation can protect itself from bad news. He outlines this view as follows: 'Also in times of adversity, widespread belief in an organization's good character may dampen the delegitimating effect of isolated failures, miscues and reversals'. Secondly, there are low barriers to entry which allows many NPOs to be set up. This can make it difficult to distinguish between credible and non-credible NPOs.

Suchman (1995) draws a distinction between strategic legitimacy and institutional legitimacy. Strategic legitimacy involves the deliberate use of symbols to garner support for the organisation. This also involves organisational management looking out to determine what needs to be done to pursue the organisation's goals. Whereas institutional legitimacy requires the organisation to conform to expectations. Therefore, in the context of performance measurement by NPOs, organisations pursuing strategic legitimacy will use performance indicators to show that they are spending resources well and are making a difference. In the context of scandals impacting the NPO sector in Ireland, it is intended that this will protect the organisation's funding. Suchman (1995) also argues that communication is a crucial part of managing legitimacy.

The annual report is a crucial means of communications for NPOs and can be used as an opportunity to gain public trust by setting out detailed information for 
stakeholders which can help win acceptance from the general public and demonstrate competence (Flack and Ryan, 2003). As such, the annual report can help the organisation gain or maintain its legitimacy through the provision of performance information. Furthermore, it is postulated that short reports that meet minimum requirements are a lost opportunity (Grant Thornton, 2013, p. 3), which is outlined as follows: 'Annual reports represent a real opportunity for organisations to demonstrate transparency and trust showing how they are governed, what they have achieved and their culture...minimalist annual reports comply with the law but, we believe, are a wasted opportunity.' Furthermore, Flack and Ryan (2003) suggest that the contents of the annual report can provide a window into what is deemed important by the organisation.

It is argued that the annual report is a key mechanism of accountability to the organisation's stakeholders and that the annual report can tell the performance story (Connolly and Hyndman, 2003; Connolly et al., 2013). The information provided should cover areas such as governance arrangements, outcomes achieved and how the money was spent. It is also suggested that non-financial information is very important in fulfilling the accountability requirements of NPOs. Hyndman (1990, p. 298) outlines the importance of non-financial information in the following terms: '...contributors provided resources for altruistic rather than economic reasons and would be primarily interested in the past achievements of, and future plans regarding charitable objectives. These objectives would largely be expressed in non-financial terms.' Therefore, disclosures can help to legitimise the organisation's actions (Kent and Zunker, 2013).

\section{Difficulties in Measuring NPO Performance}

In order to achieve legitimacy as outlined above, the measures used must be seen to be legitimate (Luke et al., 2013). The measurement of performance in NPOs is inherently difficult and most of the difficulties faced by NPOs in measuring performance arise from the characteristics of NPOs (Taylor and Taylor, 2014). These include their unique culture, diffuse power structures and special value systems (Cairns et al., 2005). This may make it difficult for NPOs to engage in the concept of performance measurement because it may distract staff away from the real mission of the organisation (Moxham, 2010, p. 348), and Moxham outlines this point of view (from the perspective of an international aid organisation) in the following terms 'As the fundamental reason ... was the activity of alleviating poverty, some staff and partners felt that it was this activity that was important rather than the measurement of outcome or impact. A number of staff felt that (they) should be "walking with the poor" and should not be asking questions about effectiveness or about the quality of work; "We should just be supporting them".'

Furthermore, it is suggested that they have multiple and nebulous goals (Callen et al., 2010). Therefore, the key challenge involves developing explicit and quantifiable objectives while at the same time allowing for the more qualitative nature of the work to be measured (Connolly and Hyndman, 2004). In addition, the aspirational nature of the organisations' goals and the long-term nature of many of these goals (Dacombe, 2011) make it difficult to capture the right kind of people changing data to allow for an assessment of progress (Carnochan et al., 2014). Furthermore, it is 
suggested that it can be difficult to isolate the effect of the efforts of the NPOs from the efforts of other organisations (Brecknell et al., 2011).

The legitimacy of the organisation may be undermined by the existence of many stakeholders because the different stakeholders may measure performance in different ways (Cairns et al., 2005). This is compounded by the distinctive ownership and governance structures in place (Billis and Glennerster, 1998, p. 81) and they outline the problems that complexity causes in the following terms: '.. the traditional division of stakeholders, such as owners, paid staff and consumers or users is replaced in voluntary agencies by a bewildering complexity of overlapping roles'. Finally, NPOs have no bottom line against which to measure performance (Callen et al., 2010). This can be contrasted to for profit organisations, where it can be suggested that the ultimate measure of success is profit. Forbes $(1998$, p. 184) suggests that NPOs will have difficulty 'developing surrogate quantitative measures of organizational performance... because [they] frequently have goals that are amorphous and offer services that are intangible'.

However, it is important to realise that it is not possible to gather perfect performance information (Connolly and Hyndman, 2003), and it is suggested that performance data involve finding a balance between what is affordable, available and appropriate. It is argued that these difficulties can be overcome, ensuring legitimacy by establishing a consensus among the stakeholders on the key performance indicators and that the information is used for organisation learning rather than apportioning blame (Moxham, 2014). The importance of legitimacy in ensuring organisational survival has been outlined above. Legitimacy can be obtained by NPOs by meeting the society's expectations of the society. Therefore, managers must understand what society expects of the organisation and work towards meeting these expectations (Moxham, 2010). However, if these expectations are unrealistic, then managers must challenge these (Herman and Renz, 2008).

\section{PERFORMANCE ELEMENTS}

The absence of a bottom-line figure such as profit makes it difficult to measure the overall organisational efficiency and effectiveness. Therefore, it is argued that a multi-dimensional approach is required for measuring performance (Lecy et al., 2012). It is suggested that there are three broad elements that can be examined (Goodin, 2003): intentions or motives of the organisation, their actions - what they did, and their results - what they achieved. Connolly and Dhanani (2009) develop this further when they suggest that intentions can be examined through the objectives that they are working towards, that their actions can be examined through their activities and programmes, and that the results can be examined in terms of the extent through which they have achieved their mission and objectives. A review of the literature suggests a wide variety of possible performance indicators that could be used by NPOs to measure their performance in non-financial terms. The key elements are outlined in Table 1 (with examples drawn from annual reports) and are mapped to Goodin's elements - intentions, actions and results. 


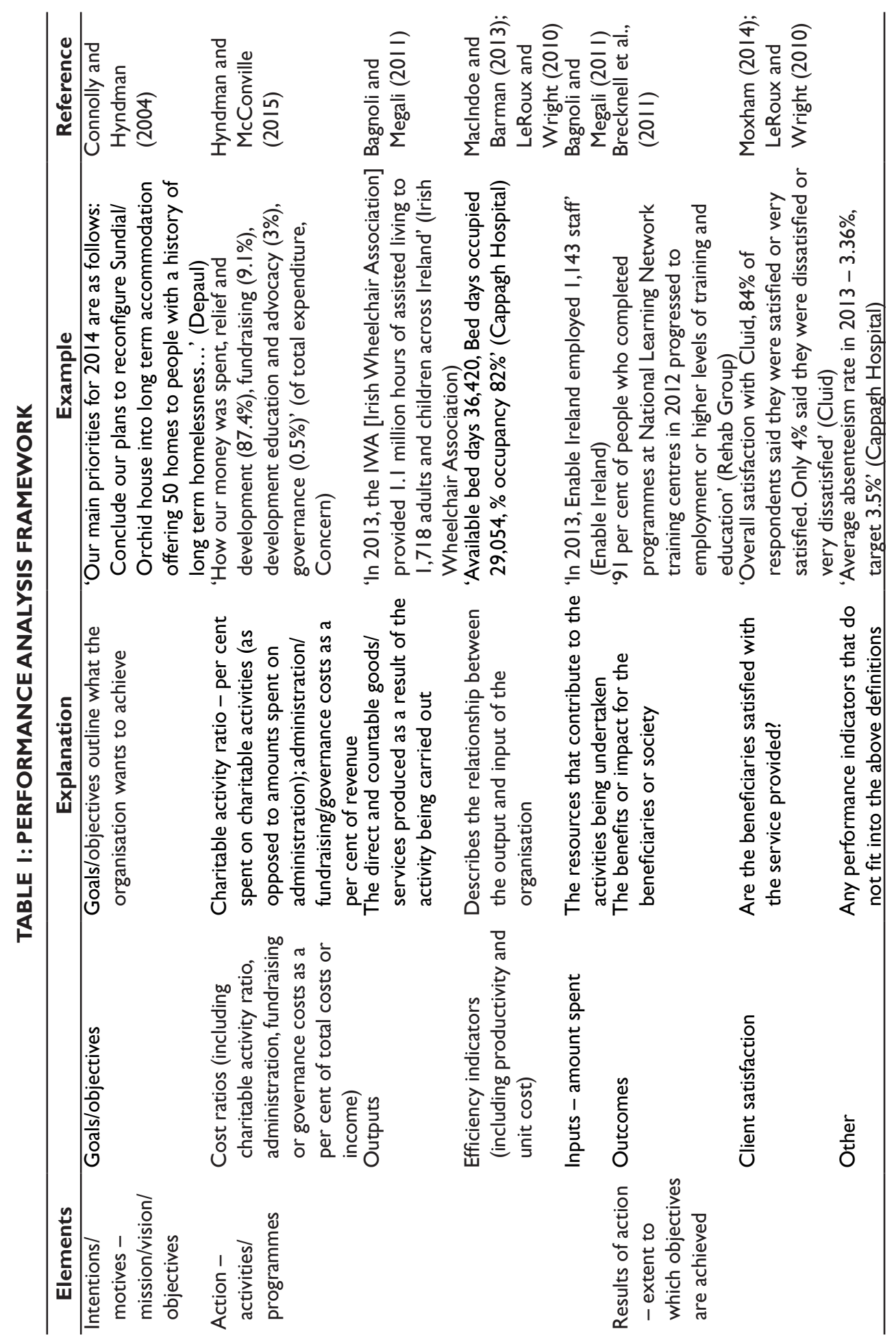


Connolly and Hyndman (2003) suggest that two of the key pieces of information sought by outsiders are a statement of the goals/objectives of the organisation and administration cost which they suggest is a financial indicator of efficiency. In relation to goals and objectives, it is argued that these should form the basis of developing a performance management system and that NPOs need to focus their limited resources on a small number of objectives (Kaplan, 2001). Otherwise, they will be ineffective. Kaplan (2001, p. 359) outlines this view in the following terms: 'Nonprofits ... have to focus their limited resources on a limited set of objectives and constituents. Attempting to be everything for everyone virtually guarantees organizational ineffectiveness.' With regard to costs, the focus has been moved to look at a wider definition of costs and includes fundraising, governance and administration (Hyndman and McConville, 2015; Sargeant et al., 2009). In addition, there is an increased focus on how much of the funds raised are spent on the charitable activities for which the funds were raised (Connolly and Dhanani, 2006). However, there is a danger that a reduction in administrative expenditure could reduce the overall organisational effectiveness (Tinkelman and Donabedian, 2007).

Bagnoli and Megali (2011) suggest that measuring the inputs, outputs and outcomes are important for NPOs. Other indicators suggested can be put under broad category of efficiency (which relates the organisation's outputs with regard to its inputs or the amount of input per unit of output) and include indicators such as unit cost and productivity (LeRoux and Wright, 2010; MacIndoe and Barman, 2013). Finally, some measurement of client satisfaction is deemed important (Moxham, 2014; LeRoux and Wright, 2010) as it is suggested that meeting the needs of the organisations' stakeholders is how NPOs need to measure success (Kaplan, 2001).

\section{METHODOLOGY}

The purpose of this paper is to build on the earlier work of Connolly and Hyndman (2004) by examining through the lens of legitimacy theory, quantity and variety of performance indicators published by a sample of large Irish NPOs. The suggestion would be that the greater the quantity and variety of information being provided, the greater the assurances that the general public would have that their funds are being spent well. The empirical work in this paper is based on a detailed analysis of the annual report published by 50 larger NPOs in Ireland (Boardmatch Ireland, 2013) to determine the quantity and variety of performance information outlined in the annual report. The latest annual report was downloaded from the NPO's website.

Annual reports are generally recognised as key documents in the discharge of accountability to external users, and all NPOs in both Ireland and the UK are required to publish such documents. The Corporate Report (Accounting Standards Committee, 1975, p. 16) states that such information packages are 'the primary means by which management of an entity is able to fulfil its reporting responsibility'. It is argued that more substantial annual reports can improve the level of accountability (Dobell and Zussman, 1981). As statutory documents in most Western economies, annual 
reports attract a degree of authenticity not associated with other reporting formats and are often the principal means through which management fulfils its reporting obligations (Boyne and Law, 1991; Coy et al., 2001; Gray et al., 2006; Kent and Zunker, 2013; Leung et al., 2015). The importance of the annual report is outlined in the following terms by Dhanani and Connolly (2012, p. 1141): 'As a statutory document in most western economies, it attracts a degree of authenticity not associated with other such media and has become the principal means through which management fulfil their reporting responsibilities'.

A performance framework was developed based on the literature (Table 2). For analysis purposes, information was considered disclosed if it was highlighted in some way (hard copy) and not contained in the main narrative of the annual report (soft copy). This approach was used before (Connolly and Hyndman, 2004), where it was argued that soft copy was difficult for users to isolate and use, as it is often embedded in a mass of subjective comment. In addition, it is argued that such information may be given in a form that may make it difficult for the user to understand its significance (Hyndman, 1990). While it could be argued that this is just a matter of presentation, information that is highlighted and concise is deemed to be substantially more useful in terms of communicating to users; this is particularly the case where users of annual reports have limited resources and are unlikely to be able to cross-examine the management of the organisation.

TABLE 2: PERFORMANCE INDICATORS PUBLISHED BY IRISH NPOS

\begin{tabular}{|c|c|c|c|c|c|}
\hline $\begin{array}{l}\text { Types of } \\
\text { Indicators }\end{array}$ & $\begin{array}{c}\text { Total } \\
\text { Number }\end{array}$ & $\%$ & $\begin{array}{l}\text { No. of } \\
\text { Organisations } \\
\text { Who Report } \\
\text { This Type of } \\
\text { Indicator }\end{array}$ & $\begin{array}{l}\quad \% \text { of } \\
\text { Organisations } \\
\text { Who Report } \\
\text { This Type of } \\
\text { Indicator }\end{array}$ & $\begin{array}{l}\% \text { of Organisations } \\
\text { Who Report This } \\
\text { Type of Indicator } \\
\text { in Connolly and } \\
\text { Hyndman (2004) }\end{array}$ \\
\hline Goals/objectives & $\mathrm{n} / \mathrm{a}$ & $\mathrm{n} / \mathrm{a}$ & 15 & 30 & 49 \\
\hline $\begin{array}{l}\text { Cost information } \\
\text { (administration/ } \\
\text { fundraising or } \\
\text { governance) }\end{array}$ & II & 2 & 11 & 22 & $n / a$ \\
\hline Inputs & 89 & 13 & 48 & 96 & 13 \\
\hline Outputs & 340 & 50 & 32 & 64 & 30 \\
\hline Efficiency & 32 & 5 & 6 & 12 & 2 \\
\hline Outcomes & 9 & I & 6 & 12 & 27 \\
\hline Client satisfaction & 15 & 2 & 6 & 12 & $\mathrm{n} / \mathrm{a}$ \\
\hline Other & 178 & 27 & 30 & 60 & $\mathrm{n} / \mathrm{a}$ \\
\hline Total & 674 & 100 & & & \\
\hline
\end{tabular}

Definitions and rules ${ }^{1}$ were developed to reduce the impact of subjectivity and these are outlined in Table 1. The rules include: information presented in more than one way is only counted once in its more detailed form and performance indicators had to be measurable in order to be included in the analysis. 


\section{FINDINGS}

Previous work by Connolly and Hyndman (2004) showed that Irish NPOs were publishing a limited amount of performance information. A summary of their findings are outlined in Table 2. This study was based on fifteen large NPOs in Ireland (defined as having an income greater than $£ 650 \mathrm{~K}$ ) and sixty eight small Irish NPOs (defined as having income greater than $£ 100 \mathrm{k}$ but less than $£ 650 \mathrm{~K}$ ). A comparison of the findings of Connolly and Hyndman (2004) findings and this study would suggest that the reporting of goals/objectives and outcomes has disimproved; while the reporting of inputs, outputs and efficiency has improved over the intervening years. The annual reports for the 50 NPOs were examined to determine the quantity and variety of performance indicators disclosed. The reports are analysed using the performance framework outlined in Table 1. The results of this analysis are summarised in Table 2 which shows that the 50 organisations are reporting 674 performance indicators across seven headings.

In relation to goals/objectives, only fifteen (30 per cent) organisations set out goals or objectives. This is likely to make it difficult for the readers of the annual report to have a clear picture of what the organisation was trying to achieve. The discussion above also suggests that the goals/objectives provide the starting point for developing the performance management system. Therefore, it could be argued that the absence of goals makes the assessment of the performance information provided more difficult as the reader may not be sure what the organisation is trying to achieve.

In relation to the performance indicators found in the annual reports, the three most frequently reported are inputs, outputs and 'other'. Overall, these account for 90 per cent of all of the performance indicators reported. In relation to inputs (e.g., staff numbers and/or income), these total 89 for all 50 organisations and account for 13 per cent of the performance indicators outlined. Furthermore, 48 (96 per cent) of the organisations report at least one input indicator. With regard to outputs, these total 340 represent 50 per cent of all of the performance indicators outlined. Furthermore, 32 organisations (64 per cent) outline at least one output indicator, but a detailed analysis shows that 70 per cent of the output indicators are accounted for by ten organisations. Therefore, the remaining organisations report a small number of output indicators. The term 'other' indicators captures all of the indicators that do not fall under the variables administration costs, outputs, inputs, efficiency, outcomes and customer satisfaction. Therefore 'other' indicators amount to 178 (27 per cent of the total) and 30 organisations (60 per cent) have at least one 'other' indicator.

In relation to information on costs, it was suggested above that this is a key measure of efficiency as it shows how much of the funds donated are spent on the end service. In the light of recent controversies, it would be expected that this would be a key indicator for NPOs as it may help to regain the public's trust by showing how the funds raised are being used. Therefore, it is surprising that only 11 organisations (22 per cent) outline a performance indicator for costs. However, it should be noted that there would need to be clear definitions as to what administration costs are and what programme costs are. Otherwise, NPOs may be tempted to change their allocations to appear more efficient (Tinkelman and Donabedian, 2007). 
It is suggested that indicators such as outputs are short-term indicators and that organisations need long-term indicators covering areas such as outcomes (Kaplan, 2001). In total, there are nine outcome indicators and only six organisations report such indicators. This would suggest that Irish NPOs may be unwilling or unable to provide such information. This is a matter of concern as organisations also need to be able to determine the impact they are having on the lives of their clients. But the discussion above suggests that this type of information is difficult to obtain due to the timescale involved (it may take many years to obtain information on the impact of a service and the outcome may be affected by many factors outside the control of the NPO) and the costs involved in obtaining this type of information. This latter point in relation to costs suggests that if an NPO invests in systems to capture information on outcomes, this may have a negative impact on the costs.

Indicators of efficiency account for 5 per cent of the total (32 indicators). However, 23 of these are outlined by one organisation. Therefore, only six organisations in total outline an efficiency indicator. In relation to client satisfaction, another key indicator identified in the literature, a total of fifteen indicators are outlined by six organisations. Again, this would suggest that organisations may be unwilling or unable to develop indicators of client satisfaction.

In overall terms, indicators of efficiency (including information on costs), outcomes and client satisfaction account for 8 per cent of the indicators reported. However, only six NPOs (12 per cent) report an indicator under each of these three categories. It could be argued that these three headings are likely to be of greater importance in communicating organisational efficiency and effectiveness to the wider public.

While, the overall number of performance indicators being published might suggest that Irish NPOs were publishing a reasonable amount of performance information (with an average of 13.5 indicators per organisation), a review of the range of performance indicators being published by the 50 organisations demonstrates that this is misleading. Table 3 shows that twenty organisations (40 per cent) outline five or less indicators, while twelve organisations publish twenty-one or more indicators. These twelve organisations account for 64 per cent of the indicators published by the fifty NPOs. This shows that the overall figures are being heavily skewed by a small number of organisations publishing a large number of performance indicators. This is not to suggest that the more indicators that a NPO publishes the better, as many of these may be low-level and unfocused performance indicators which may confuse the reader. The abvoe discussion suggests that in the absence of an all-embracing performance indicator such as profit, a variety of

TABLE 3: RANGE OF INDICATORS PUBLISHED BY IRISH NPOS

\begin{tabular}{ccc}
\hline Range & No. of Organisations & \% of Organisations \\
\hline $0-5$ & 20 & 40 \\
$6-10$ & 9 & 18 \\
$11-20$ & 9 & 18 \\
$21+$ & 12 & 24 \\
& 50 & 100 \\
\hline
\end{tabular}


performance indicators will be required to give the readers of the annual report a rounded view of organisational performance. Table 3 suggests that many NPOs are not publishing sufficient performance information that will allow the readers of their annual report (and potential donors) to evaluate the overall efficiency and effectiveness in delivering services to clients.

\section{CONCLUSIONS}

The purpose of this paper was to examine the quantity and variety of performance information being provided by 50 of the largest NPOs in Ireland through the lens of legitimacy theory. Legitimacy theory suggests that organisations can gain acceptance by meeting society's expectations (Samkin and Schneider, 2010) and that legitimacy is based on trust and maintenance of a 'social contract'. In other words, the NPOs' values must be in accord with those of wider society (Lindblom, 1994; Mathews, 1993; Shocker and Sethi, 1973). Due to the nature of their work, NPOs in Ireland have a valued status, but this makes them particularly susceptible to disillusionment when things go wrong (Gibelman and Gelman, 2004). It was contended above that trust and public confidence are important for NPOs (Yang et al., 2014) as they give them access to continued funding (Luke et al., 2013; Suchman, 1995). The literature suggest that the provision of performance information can help maintain public confidence and trust (Connolly and Dhanani, 2009; Dhanani and Connolly, 2012; Tremblay-Boire and Prakesh, 2015).

A number of scandals in Irish NPOs (involving excessive pay levels and misuse of funds) have reduced confidence in NPOs and raised concerns about whether the NPO sector is delivering value for money. Questions have been raised about the overall number of NPOs and the level of duplication (e.g., over one hundred cancer charities have been listed in the CRA website). As a result, the fundraising efforts of all NPOs have been impacted. In order to address these concerns, the expectation would be that the 50 large Irish NPOs surveyed would be publishing sufficient performance information to show that they are well managed and making a difference.

However, the findings outlined above suggest that there is much room for improvement. While overall, the 50 NPOs are reporting 674 performance indicators. Most of these are produced by a small number of NPOs (with twelve NPOs accounting for 64 per cent of the total and twenty NPOs report five or less indicators). Furthermore, there is very limited reporting of outcomes (there were nine indicators across six organisations); client satisfaction (fifteen indicators in total across six organisations) and cost information (eleven indicators in eleven organisations). Therefore, it is unlikely that the reader of an annual report would be able to assess whether the NPO was being run well and was making a difference.

The findings are somewhat surprising as it would be expected that NPOs would be looking to protect themselves against a general backlash against the wider NPO sector. Such a process was described as 'strategic legitimacy' (Suchman, 1995), and this involves managers using symbols (such as performance indicators) to garner support for the organisation. In addition, strategic legitimacy also requires managers to look outwards to determine what needs to be done in order to achieve the 
organisation's goals. Communication is a critical part of managing legitimacy (Suchman, 1995) and the disclosure of performance can help legitimise organisational actions (Kent and Zunker, 2013). It is also suggested that the annual report is a key tool for communicating organisational achievements (Dhanani and Connolly, 2012). The evidence presented here suggests that Irish NPOs need to increase the level of performance reporting if they want to maintain or regain their legitimacy and meet society's expectations. This will require them to engage with their stakeholders to identify the type of information that would convey the success of the organisation.

In the absence of a bottom-line figure, there is much debate on how NPOs can measure their performance. Goodin (2003) suggests that performance can be assessed across three broad elements: intentions, actions and results. The literature identified a number of key of indicators that could be mapped onto these three elements. These include goals/objectives, costs, inputs, outputs, efficiency, outcomes and client satisfaction, which are outlined in Table 1.

However, there are a number of difficulties in assessing the performance of NPOs. These include the fact that NPOs have multiple objectives that are often nebulous in nature and have a long-term focus (Forbes, 1998). Furthermore, the culture of NPOs is different with many stakeholders having an input into policy-making and the sense that NPOs have a higher mission that may be sullied through the use of management tools such as performance indicators (Cairns et al., 2005; Moxham, 2010). But it is suggested that these difficulties can be ameliorated through stakeholder engagement on what constitutes success and that performance information is used for organisational learning rather than apportioning blame (Moxham, 2010, 2014).

The research presented here is confined to the information contained in the annual report. It is possible that NPOs may be using more performance information than is indicated by this research. Therefore, further research could determine the level of performance information used internally, review how this might be conveyed better to the NPOs stakeholders and examine reasons why many NPOs are reluctant to publish performance information. Other research areas could include research with stakeholders to determine the type of performance information that NPOs should be providing and whether the funding sources impact the level of performance reporting.

Overall, this paper contributes to insights into a major area of weakness in NPO reporting, namely the reporting of performance. The low level of performance reporting threatens to undermine the legitimacy and trust of the general public in individual NPOs but also in the whole NPO sector. Recent scandals suggest that the 'taken-for-granted goodness' of NPOs is no longer valid and that NPOs need to develop a strategy on how they can report on their efficiency and effectiveness. It is hoped that these research findings will contribute to the debate on how performance reporting can be developed so that trust and legitimacy can be maintained and developed in Ireland and elsewhere.

\section{ENDNOTES}

A copy of the rules used can be requested from the author. 


\section{APPENDIX 1}

LISTING OF NPOS AND THE NUMBER OF PERFORMANCE INDICATORS CONTAINED IN THEIR ANNUAL REPORTS

\begin{tabular}{|c|c|c|c|}
\hline & Charity Name & $\begin{array}{c}\text { Revenue } \\
€\end{array}$ & $\begin{array}{c}\text { No. of indicators } \\
\text { outlined in annual } \\
\text { report }\end{array}$ \\
\hline $\mathrm{I}$ & Ability West & 22.4 & 2 \\
\hline 2 & Acquired Brain Injury Ireland & 12.1 & 6 \\
\hline 3 & Barnardos & 22.7 & 11 \\
\hline 4 & Bothair & 6.4 & 7 \\
\hline 5 & Cappagh National Orthopaedic Hospital & 35.2 & 58 \\
\hline 6 & Carriglea Cairde Services & 10.0 & 2 \\
\hline 7 & Cheshire Ireland & 29.5 & I \\
\hline 8 & Childvision & 6.7 & I \\
\hline 9 & Cluid Housing Association & 13.7 & 11 \\
\hline 10 & Concern Worldwide & 127.0 & 14 \\
\hline 11 & Cope Foundation & 53.0 & 7 \\
\hline 12 & Cork Simon Community & 7.1 & 10 \\
\hline 13 & Depaul Ireland & 7.6 & 13 \\
\hline 14 & Dublin Simon Community & 5.4 & 11 \\
\hline 15 & Enable Ireland & 46.0 & 41 \\
\hline 16 & Focus Ireland & 18.3 & 16 \\
\hline 17 & Goal & 60.5 & 4 \\
\hline 18 & Gorta & 5.1 & 8 \\
\hline 19 & Irish Cancer Society & 20.2 & 26 \\
\hline 20 & Irish Heart Foundation & 5 & 10 \\
\hline 21 & Irish Society for the Prevention of Cruelty to Children & 5.3 & 20 \\
\hline 22 & Irish Wheelchair Association & 51.0 & 25 \\
\hline 23 & Kerry Parents and Friends Association & 9.0 & I \\
\hline 24 & Mater Misercordiae Hospital & 258.0 & 9 \\
\hline 25 & Milford Care Centre & 17.0 & 25 \\
\hline 26 & Miseann Cara & 16.2 & 3 \\
\hline 27 & Multiple Sclerosis Ireland & 6.7 & 13 \\
\hline 28 & National College of Ireland & 17.2 & 44 \\
\hline 29 & $\mathrm{NCBI}$ & 12.0 & I \\
\hline 30 & Our Lady's Children's Hospital Crumlin & 112.3 & 2 \\
\hline 31 & Our Lady's Hospice and Care & 38.0 & 34 \\
\hline 32 & Oxfam Ireland & 11.8 & 7 \\
\hline 33 & Peamount Healthcare & 23.9 & 5 \\
\hline 34 & Plan Ireland & 12.2 & 35 \\
\hline 35 & Prosper Fingal & 7.0 & 7 \\
\hline 36 & Rehab Group & 178.0 & 42 \\
\hline 37 & Respond & 15.1 & 1 \\
\hline
\end{tabular}


(CONTINUED)

\begin{tabular}{llcc}
\hline \multicolumn{1}{c}{ Charity Name } & $\begin{array}{c}\text { Revenue } \\
€\end{array}$ & $\begin{array}{c}\text { No. of indicators } \\
\text { outlined in annual } \\
\text { report }\end{array}$ \\
\hline 38 & St. Francis Hospice Dublin & 12.1 & 21 \\
39 & St. John of God Hospital and St. Joseph's Centre & 31.3 & 1 \\
40 & St. Joseph's Foundation & 14.8 & 2 \\
41 & St. Michael's House & 87.0 & 5 \\
42 & St. Patrick's Hospital & 13.0 & 53 \\
43 & Self Help Africa & 13.1 & 5 \\
44 & SOS Kilkenny & 7.7 & 2 \\
45 & Sunbeam House Services & 22.2 & 2 \\
46 & The Alzheimer's Society of Ireland & 15.1 & 3 \\
47 & The Economic and Social Research Institute & 13.7 & 0 \\
48 & Unicef Ireland & 6.0 & 26 \\
49 & Western Care Association & 29.2 & 19 \\
50 & World Vision of Ireland & 6.6 & 2 \\
\hline
\end{tabular}

\section{REFERENCES}

Accounting Standards Committee (1975). The Corporate Report, London: ASC.

Bagnoli, L. and Megali, C. (2011). Measuring Performance in Social Enterprises, Nonprofit and Voluntary Sector Quarterly, Vol. 40, No. 1, pp. 149-165.

Billis, D. and Glennerster, H. (1998). Human Services and the Voluntary Sector: Towards a Theory of Comparative Advantage, Journal of Social Policy, Vol. 27, No. 1, pp. 79-98.

Boardmatch Ireland (2013). Charity 100 Index, Dublin: Boardmatch Ireland.

Boyne, G. and Law, J. (1991). Accountability and Local Authority Annual Reports: The Case of the Welsh District Councils, Financial Accountability \& Management, Vol. 7, No. 3, pp. 179-194.

Brecknell, P., Harrison, K. and Robert, N. (2015). Impact Reporting in the UK Charity Sector, <http://www.cfg.org.uk/resources/ /media/Files/Resources/Impacts\%20reporting \%20in\%20the\%20UK\%20Charity\%20Sector.ashx 2011>, accessed 5 May 2015.

Cairns, B., Harris, M., Hutchinson, R. and Tricker, M. (2005). Improving Performance? The Adoption and Implementation of Quality Systems in UK Nonprofits, Nonprofit Management \& Leadership, Vol. 16, No. 2, pp. 135-151.

Callen, J., Klein, A. and Tinkelman, D. (2010). The Contextual Impact of Nonprofit Board Composition and Structure on Organizational Performance: Agency and Resource Dependency Perspectives, Voluntas: International Journal of Voluntary and Nonprofit Organisation, Vol. 21, No. 1, pp. 101-125.

Campbell, D., Moore, G. and Shrives, P. (2006). Cross-Sectional Effects in Community Disclosure, Accounting, Auditing \& Accountability Journal, Vol. 19, No. 1, pp.96-114.

Carnochan, S., Samples, M., Myers, M. and Austin, M.J. (2014). Performance Measurement Challenges in Nonprofit Human Service Organizations, Nonprofit and Voluntary Sector Quarterly, Vol. 43, No. 6, pp. 1014-1032.

Charities Regulatory Authority (2014). Functions of the Charities Regulatory Authority, <http:// www.charitiesregulatoryauthority.ie/en/cra/pages/wp16000059>, cited 11 December 2014.

Connolly, C. and Dhanani, A. (2006). Accounting Narratives: The Reporting Practices of Britsh Charities, Journal for Public and Nonprofit Services, Vol. 3, No. 5, pp. 39-62. 
Connolly, C. and Dhanani, A. (2009). Narrative Reporting by UK Charities, London: The Association of Chartered Certified Accountants.

Connolly, C. and Hyndman, N. (2003). Performance Reporting by UK Charities: Approaches, Difficulties and Current Practices, Edinburgh: Institute of Chartered Accountants of Scotland.

Connolly, C. and Hyndman, N. (2004). Performance Reporting: A Comparative Study of British and Irish Charities, The British Accounting Review, Vol. 36, No. 2, pp. 127-154.

Connolly, C., Hyndman, N. and McConville, D. (2013). UK Charity Accounting: An Exercise in Widening Stakeholder Engagement, The British Accounting Review, Vol. 45, No. 1, pp. 58-69.

Coy, D., Fischer, M. and Gordon, T. (2001). Public Accountability: A New Paradigm for College and University Reports, Critical Perspectives in Accounting, Vol. 12, No. 1, pp. 1-31.

Dacombe, R. (2011). Can We Argue Against It? Performance Management and State Funding of Voluntary Organisations in the UK, Public Money and Management, Vol. 31, No. 3, pp. 159-166.

Deegan, C. (2002). Introduction: The Legitimising Effect of Social and Environmental Disclosures - A Theoretical Foundation, Accounting, Auditing \& Accountability Journal, Vol. 15, No. 3, pp. 282-311.

Dhanani, A. and Connolly, C. (2012). Discharging Not-for-Profit Accountability: UK Charities and Public Discourse, Accounting, Auditing \& Accountability Journal, Vol. 25, No. 7, pp. 1140-1169.

Dobell, R. and Zussman, D. (1981). An Evaluation Strategy for Government: If Politics is Theatre Then Evaluation Is (Mostly) Art, Canadian Public Administration, Vol. 24, No. 3, pp. 404-427.

Flinders, M. (2011). Daring to Be Daniel, The Pathology of Politicized Accountability in a Monitory Democracy, Administration \& Society, Vol. 43, No. 5, pp. 595-619.

Forbes, D.P. (1998). Measuring the Unmeasurable: Empirical Studies of Nonprofit Organization Effectiveness from 1977 to 1997, Nonprofit and voluntary sector quarterly, Vol. 27, No. 2, pp. 183-202.

Gibelman, M. and Gelman, S. (2004). A Loss of Credibility: Patterns of Wrongdoing Among Nongovernmental Organizations, Voluntas: International Journal of Voluntary and Nonprofit Organisation, Vol. 15, No. 4, pp. 355-381.

Goodin, R. (2003). Democratic Accountability: The Distinctiveness of the Third Sector, European Journal of Sociology, Vol. 44, No. 3, pp. 359-371.

Gray, K., Bebbington, J. and Collison, D. (2006). NGOs, Civil Society and Accountability: Making the People Accountable to Capital, Accounting, Auditing and Accountability Journal, Vol. 19, No. 3, pp. 319-348.

Herman, R.D. and Renz, D.O. (2008). Advancing Nonprofit Organizational Effectiveness Research and Theory Nine Theses, Nonprofit Management E Leadership, Vol. 18, No. 4, pp. 399-415.

Hyndman, N. (1990). Charity Accounting - An Empirical Study of the Information Needs of Contributors to UK Fund Raising Charities, Financial Accountability and Management, Vol. 6, No. 4, pp. 295-307.

Hyndman, N. and McConville, D. (2015). Transparency in Reporting on Charities' Efficiency A Framework for Analysis, Nonprofit and Voluntary Sector Quarterly, Vol. 45, No. 4, pp. 844-865.

Jeavons, T.H. (1994). Stewardship Revisted: Secular and Sacred Views of Governance and Management, Nonprofit and Voluntary Sector Quarterly, Vol. 23, No. 2, pp. 107-122.

Kaplan, R.S. (2001). Strategic Performance Measurement and Management in Nonprofit Organizations, Nonprofit Management \& Leadership, Vol. 11, No. 3, pp. 353-370.

Kent, P. and Zunker, T. (2013). Attaining Legitimacy by Employee Information in Annual Reports, Accounting, Auditing \& Accountability Journal, Vol. 26, No. 7, pp. 1072-1106. 
Lecy, J.D., Schmitz, H.P. and Swedlund, H. (2012). Non-Governmental and Not-for-Profit Organizational Effectiveness: A Modern Synthesis, Voluntas:International Journal of Voluntary and Nonprofit Organisation, Vol. 23, No. 2, pp. 434-457.

LeRoux, K. and Wright, N. (2010). Does Performance Measurement Improve Strategic Decision Making? Findings from a National Survey of Nonprofit Social Service Agencies, Nonprofit and Voluntary Sector Quarterly, Vol. 39, No. 4, pp. 571-587.

Leung, S., Parker, L. and Courtis, J. (2015). Impression Management through Minimal Narrative Disclosure in Annual Reports, British Accounting Review, Vol. 47, No. 3, pp. 275-289.

Lindblom, C.K. (1994). Implications of Organizational Legitimacy for Corporate Social Performance and Disclosure, in Critical Perspectives on Accounting Conference, New York.

Luke, B., Barraket, J. and Eversole, R. (2013). Measurement as Legitimacy Versus Legitimacy of Measures: Performance Evaluation of Social Enterprise, Qualitative Research in Accounting and Management, Vol. 10, No. 3, pp. 234-258.

MacIndoe, H. and Barman, E. (2013). How Organisational Stakeholders Shape Performance Measurement in Nonprofits: Exploring a Multidimensional Measure, Nonprofit and Voluntary Sector Quarterly, Vol. 42, No. 4, pp. 716-738.

Mathews, M.R. (1993). Socially Responsible Accounting, London: Chapman Hall.

Moxham, C. (2010). Help or Hindrance? Examining the Role of Performance Measurement in UK Nonprofit Organizations, Public Performance \& Management Review, Vol. 33, No. 3, pp. 342-354.

Moxham, C. (2014). Understanding Third Sector Performance Measurement System Design: A Literature Review, International Journal of Productivity and Performance Management, Vol. 63, No. 6, pp. 704-726.

Mueller, J., Williams, D., Higgins, A. and Tou, M. (2005). The Measurement of Responsible Governnace and Mangement of NPOs in New Zealand: An Evaluation Tool for NPOs, Donors and Government, Corporate Governance, Vol. 5, No. 2, pp. 159-173.

Samkin, G. and Schneider, A. (2010). Accountability, Narrative Reporting and Legitimation, Accounting, Auditing \& Accountability Journal, Vol. 23, No. 2, pp. 256-289.

Sargeant, A., Ford, B. and West, D.C. (2006). Perceptual Determinants of Nonprofit Giving Behaviour, Journal of Business Research, Vol. 59, No. 2, pp. 155-165.

Sargeant, A., Lee, S. and Jay, E. (2009). Communicating the "Realities" of Charity Costs, Nonprofit and Voluntary Sector Quarterly, Vol. 38, No. 2, pp. 333-342.

Shocker, A.D. and Sethi, S.P. (1973). An Approach to Incorporating Societal Preferences in Developing Corporate Action Strategies, California Management Review Summer, Vol. 15, No. 4, pp. 97-105.

Suchman, M.C. (1995). Managing Legitimacy: Strategic and Institutional Approaches, Academy of Management Journal, Vol. 20, No. 3, pp. 571-610.

Taylor, M. and Taylor, A. (2014). Performance Measurement in the Third Sector: The Development of a Stakeholder-Focussed Research Agenda, Production Planning \& Control, Vol. 25, No. 16, pp. 1370-1385.

Tilling, M.V. and Tilt, C.A. (2010). The Edge of Legitimacy, Accounting, Auditing and Accountability Journal, Vol. 23, No. 1, pp. 55-81.

Tinkelman, D. and Donabedian, B. (2007). Street Lamps, Alleys, Ratio Analysis, and Nonprofit Organizations, Nonprofit Management \& Leadership, Vol. 18, No. 1, pp. 5-17.

Tremblay-Boire, J. and Prakesh, A. (2015). Accountability.org: Online Disclosures by U.S. Nonprofits, Voluntas: International Journal of Voluntary and Nonprofit Organisation, Vol. 26, No. 2, pp. 693-719.

Yang, Y., Brennan, I. and Wilkinson, M. (2014). Public Trust and Performance Measurement in Charitable Organizations, International Journal of Productivity and Performance Management, Vol. 63, No. 6, pp. 779-796. 